\title{
Molecular epidemiology of Mycobacterium tuberculosis in Brazil before the whole genome sequencing era: a literature review
}

\author{
Emilyn Costa Conceição, ${ }^{1,2,3} /{ }^{+}$, Richard Steiner Salvato ${ }^{4,5}$, Karen Machado Gomes ${ }^{6}$, \\ Arthur Emil dos Santos Guimarães, ${ }^{7,8}$, Marília Lima da Conceição, ${ }^{7,8}$, \\ Ricardo José de Paula Souza e Guimarães ${ }^{9}$, Abhinav Sharma ${ }^{10}$, Ismari Perini Furlaneto ${ }^{8}$, \\ Regina Bones Barcellos ${ }^{5}$, Valdes Roberto Bollela ${ }^{11}$, Lívia Maria Pala Anselmo ${ }^{11}$, \\ Maria Carolina Sisco ${ }^{3,12}$, Cristina Viana Niero $^{13}$, Lucilaine Ferrazoli ${ }^{14}$, Guislaine Refrégier ${ }^{15}$, \\ Maria Cristina da Silva Lourenço ${ }^{2}$, Harrison Magdinier Gomes ${ }^{3}$, Artemir Coelho de Brito ${ }^{16}$, \\ Marcos Catanho ${ }^{17}$, Rafael Silva Duarte ${ }^{12}$, Philip Noel Suffys ${ }^{3}$, Karla Valéria Batista Lima ${ }^{7,8}$ \\ ${ }^{1}$ Fundação Oswaldo Cruz-Fiocruz, Instituto Nacional de Infectologia Evandro Chagas, Programa de Pós-Graduação em Pesquisa Clínica e \\ Doenças Infecciosas, Rio de Janeiro, RJ, Brasil \\ ${ }^{2}$ Fundação Oswaldo Cruz-Fiocruz, Instituto Nacional de Infectologia Evandro Chagas, Laboratório de Bacteriologia e Bioensaios em \\ Micobactérias, Rio de Janeiro, RJ, Brasil \\ ${ }^{3}$ Fundação Oswaldo Cruz-Fiocruz, Instituto Oswaldo Cruz, Laboratório de Biologia Molecular Aplicada a Micobactérias, Rio de Janeiro, RJ, Brasil \\ ${ }^{4}$ Universidade Federal do Rio Grande do Sul, Programa de Pós-Graduação em Biologia Celular e Molecular, Porto Alegre, RS, Brasil \\ ${ }^{5}$ Secretaria Estadual de Saúde do Rio Grande do Sul, Centro Estadual de Vigilância em Saúde, Centro de Desenvolvimento Científico e \\ Tecnológico, Porto Alegre, RS, Brasil \\ ${ }^{6}$ Fundação Oswaldo Cruz-Fiocruz, Escola Nacional de Saúde Pública Sergio Arouca, Centro de Referência Professor Hélio Fraga, \\ Laboratório de Referência Nacional para Tuberculose e outras Micobacterioses, Rio de Janeiro, RJ, Brasil \\ ${ }^{7}$ Universidade do Estado do Pará, Instituto de Ciências Biológicas e da Saúde, Pós-Graduação Biologia Parasitária na Amazônia, Belém, PA, Brasil \\ ${ }^{8}$ Instituto Evandro Chagas, Seção de Bacteriologia e Micologia, Ananindeua, PA, Brasil \\ ${ }^{9}$ Instituto Evandro Chagas, Laboratório de Geoprocessamento, Ananindeua, PA, Brasil \\ ${ }^{10}$ International Institute of Information Technology, Department of Data Science, Bangalore, India \\ ${ }^{11}$ Universidade de São Paulo, Departamento de Clínica Médica da Faculdade de Medicina de Ribeirão Preto, Ribeirão Preto, SP, Brasil \\ ${ }^{12}$ Universidade Federal do Rio de Janeiro, Instituto de Microbiologia Paulo de Góes, Laboratório de Micobactérias, Rio de Janeiro, RJ, Brasil \\ ${ }^{13}$ Universidade Federal de São Paulo, Departamento de Microbiologia, Imunologia e Parasitologia, São Paulo, SP, Brasil \\ ${ }^{14}$ Instituto Adolfo Lutz, Centro de Bacteriologia, Núcleo de Tuberculose e Micobacterioses, São Paulo, SP, Brasil \\ ${ }^{15}$ Universit e Paris-Saclay, Ecologie Systematique Evolution, Centre National de la Recherche Scientifique, AgroParisTech, Orsay, France \\ ${ }^{16}$ Coordenação Geral de Vigilância das Doenças de Transmissão Respiratória de Condições Crônicas, Brasília, DF, Brasil \\ ${ }^{17}$ Fundação Oswaldo Cruz-Fiocruz, Instituto Oswaldo Cruz, Laboratório de Genética Molecular de Microrganismos, Rio de Janeiro, RJ, Brasil
}

Molecular-typing can help in unraveling epidemiological scenarios and improvement for disease control strategies. A literature review of Mycobacterium tuberculosis transmission in Brazil through genotyping on 56 studies published from 1996-2019 was performed. The clustering rate for mycobacterial interspersed repetitive units - variable tandem repeats (MIRUVNTR) of 1,613 isolates were: $73 \%, 33 \%$ and $28 \%$ based on 12,15 and 24-loci, respectively; while for RFLP-IS6110 were: $84 \%$ among prison population in Rio de Janeiro, 69\% among multidrug-resistant isolates in Rio Grande do Sul, and 56.2\% in general population in São Paulo. These findings could improve tuberculosis (TB) surveillance and set up a solid basis to build a database of Mycobacterium genomes.

Key words: tuberculosis - Mycobacterium tuberculosis - genotyping - MIRU-VNTR typing - RFLP-IS6110 - Brazil

Despite being an ancient disease, tuberculosis (TB) is still the leading cause of death among infectious diseases worldwide. From 2016 to 2020, Brazil has been on the World Health Organization (WHO) list of high burden countries for TB and TB/HIV co-infection. ${ }^{(1)}$ In 2014, WHO proposed the End TB Strategy that targets TB prevention, care, control, and together with the Sus-

doi: 10.1590/0074-0276020517

Financial support: CAPES (Finance Code 001).

PNS and KVBL contributed equally to supervising this work.

+ Corresponding author: emilyncosta@gmail.com

(D) https://orcid.org/ 0000-0002-7445-6620

Received 01 October 2020

Accepted 11 February 2021 tainable Development Goals (SDGs) aimed at trying to bring TB incidence and mortality on a global level to those observed in high-income countries. ${ }^{(2,3,4,5,6)}$

The three pillars of the End TB Strategy are: (i) integrated, patient-centered TB care and prevention, bold policies, and supportive systems (including universal health coverage, social protection, and action on determinants), (ii) intensified research and (iii) innovation. To face this scenario, the main strategy includes milestones (for 2020 and 2025) and quantitative targets (for 2030 and 2035) for three high-level indicators: incidence and mortality rates, as well as the percentage of TB patients and their households. ${ }^{(3,6)}$

In 2016, a Brazilian report discussing the Global End TB Strategy program was published as a technical report and a national TB research agenda was proposed to the establishment of the National TB Research Strategy 
Plan. One of the strategies to address the gap regarding general recommendations was to "create a coordination research group on fundamental and translational research that pursues increased collaboration among various laboratories to better utilise the available knowledge of different groups". (7) One of the key endorsed research areas was regarding the investigation on host-pathogen interaction targeting new genetic, molecular, immunological, or metabolic markers, including the use of genotyping and the "omics" supporting epidemiology, new diagnostics methods, studies about new vaccines and more recently new drugs. ${ }^{(7,8)}$

The association between specific M. tuberculosis strains and the increase of anti-TB drug resistance is one of the major drivers for mortality rate increase. The investigation of transmission sources and monitoring TB strains by molecular epidemiology studies complemented by molecular typing tools is therefore essential to control TB. ${ }^{(9)}$

Spacer-oligonucleotide-typing (spoligotyping), mycobacterial interspersed repetitive units - variable number tandem repeat (MIRU-VNTR) typing and the insertion sequence 6110 - restriction fragment length polymorphism (RFLP-IS6110) are among the most used genotyping methods for M. tuberculosis complex (MTBC) strains. However, due to their different resolving power, only the latter two are used to evaluate TB transmission and perform detailed molecular epidemiology.

MIRU-VNTR is the current reference technique due its higher discriminatory power and reproducibility. Except for RFLP-IS6110, because of those characteristics and ease of interpretation and storage, both spoligotypes and MIRU-VNTR based genotypes are stored in large international databases that allow inter-laboratory comparison of patterns while RFLP-IS6110, although considerable in number, are mostly composing local databases. ${ }^{(10,11)}$

Through this systematic literature review on the use of RFLP-IS6110 and MIRU-VNTR, we aimed to (i) describe the Brazilian TB network laboratories structure, (ii) characterise molecular epidemiology studies in Brazil applied to TB; (iii) to study the genetic diversity of M. tuberculosis in the country, and (iv) to correlate these data to the national epidemiological scenario of TB.

\section{MATERIALS AND METHODS}

Data collection of the Brazilian tuberculosis policies - We have collected the information mainly from the Brazilian National Program of TB Control (NPTC), recently named as General Coordination for the Monitoring of Chronic Conditions Respiratory Transmission Diseases (Coordenação Geral de Vigilância das Doenças de Transmissão Respiratória de Condições Crônicas - CGDR), ${ }^{(12)}$ which is responsible for establishing guidelines for disease control, manuals, and reports. The national recommendations are updated and disclosed in the technical notes of the NPTC and in the publication of the Brazilian Guidelines for Tuberculosis Control (BGT$\mathrm{BC})$, first edited in 2011, and last published in 2019.(13)

Data collection on M. tuberculosis genotyping - Data were collected using PubMed (http://www.ncbi.nlm.nih. gov/pubmed), as well as the Brazilian virtual library BVS (Biblioteca Virtual em Saúde) database. For this, we used the keywords "MIRU-VNTR AND tuberculosis AND Brazil" and "RFLP AND tuberculosis AND Brazil". All papers were downloaded and information such as data, place and date of samples collections, study period, samples characteristics, genotyping techniques used, the year of publication and principal results obtained) were introduced into a Microsoft Office Excel spreadsheet (Albuquerque, United States).

Data analysis - We analysed all papers published until January 28th, 2020 summarised our approach, using the PRISMA flow diagram..$^{(14)}$

For the present review, for comparison of RFPLIS6110-DNA fingerprints generated in different laboratories and publications, ideally, having access do the DNA patterns together with their respective internal (each lane) or external (each gel) enable us to perform normalisation of the RFLP-IS6110 patterns appropriate software. ${ }^{(15)}$ However, we only had access to the figures, either in the format of banding patterns or as digitalised patterns; so, we were restricted to perform a qualitative analysis based on the mean results and on conclusions presented in most of the studies.

For reviewing of MIRU-VNTR patterns on the other hand, for each paper we were able to introduce numeric data into a single Excel file simply by reorganising the order of the published 12, 15 and 24 loci presented. The first 12 MIRU loci positions were composed by: MIRU2 (154), MIRU4 (580), MIRU10 (960), MIRU16 (1644), MIRU20 (2059), MIRU23 (2531), MIRU24 (2687), MIRU26 (2996), MIRU27 (3007), MIRU31 (3192), MIRU39 (4348) and MIRU40 (802) was adopted. For the next 12 VNTRs of the 24-MIRU-VNTR patterns, we organised according to the ETR, MTUB and QUB scheme, being ETR-A (2165), ETR-B (2461), ETR-C (577), MTUB 04 (424), MTUB 21 (1955), MTUB 29 (2347), MTUB 30 (2401), MTUB 34 (3171), MTUB 39 (3690), QUB 11 (2163b), QUB 26 (4052) and QUB 4156 (4156). For 15 MIRU-VNTR typing, the same order was adopted but removing nine loci: MIRU2 (154), MIRU20 (2059), MIRU23 (2531), MIRU24 (2687), MIRU27 (3007), MIRU39 (4348), ETR-B (2461), MTUB 04 (424) and MTUB 29 (2347).

Recent transmission was estimated by the N-1 method, using the mathematical model: number of clustered isolates minus (-) number of clusters divided (/) by the total number of isolates. ${ }^{(16)}$ The allelic diversity $(h)$ at MIRU-VNTR loci was calculated according to HunterGaston index ${ }^{(17)}$ using Bionumerics (Applied Maths, Sint-Martens-Latem, Belgium) for each set of 12,15 and 24 loci and defined as "highly discriminant" $(h>0.6)$, "moderately discriminant" $(0.3 \leq h \leq 0.6)$ or "poorly discriminant" $(h<0.3)$.

In addition, we have used TBminer (https://info-demo.lirmm.fr/tbminer//(18) to predict the MTBC lineages from MIRU-VNTR profile.

Disease distribution based on geographic mapping - The boundaries of the regional divisions of Brazil (States and Regions) applied presently were obtained on the website of the Brazilian Institute of Geography and Statistics (IBGE) (https://www.ibge.gov.br/). ${ }^{(19)}$ The coordinates of the institutions were obtained from Google 
Maps (https://www.google.com.br/maps). Data processing, interpretation, visualisation, and spatial analysis were performed via ArcGIS software (http://www.arcgis.com/). TB incidence was classified into five levels according to the WHO and being either absence of: no cases (white colour), low (1-10 - green), medium (11-50 yellow), high (51-100 cases - orange) and very high number $(>100$ - red) cases per 100,000 hab.

\section{RESULTS}

The Brazilian organisational structure for TB policies - The NPTC is linked to three governmental spheres and coordinated by the so-called Unified Health System (UHS) (Sistema Único de Saúde - SUS) that legally establishes administrative competence at the federal, state, and municipal level. These spheres are composed of the Ministry of Health, the State Health Secretariats (one for each of the 26 states and the Federal District) and the Municipal Health Secretariats, each having their respective technical and administrative sectors. ${ }^{(13)}$

The National System of Public Health Laboratories (Sistema Nacional de Laboratórios de Saúde Pública SISLAB) consists of a national network of laboratories, organised in sub-networks in a hierarchical way and with different degrees of complexities of activities related to health surveillance. There are seven laboratory categories $^{(13)}$ as represented in Fig. 1.

The Brazilian Guidelines focus basically on clinical recommendations regarding the standardisation of case finding and treatment actions with little, or no information related to genotyping data generated in Brazilian studies.

For routine TB diagnosis in clinical specimens, besides chest X-ray, collection of sputum samples for acidfast bacilli staining (Ziehl-Neelsen and/or auramine-rodamine stain) are culture in solid (Lowenstein-Jensen or Ogawa-Kudoh) (AFB) or liquid media (BACTEC MGIT

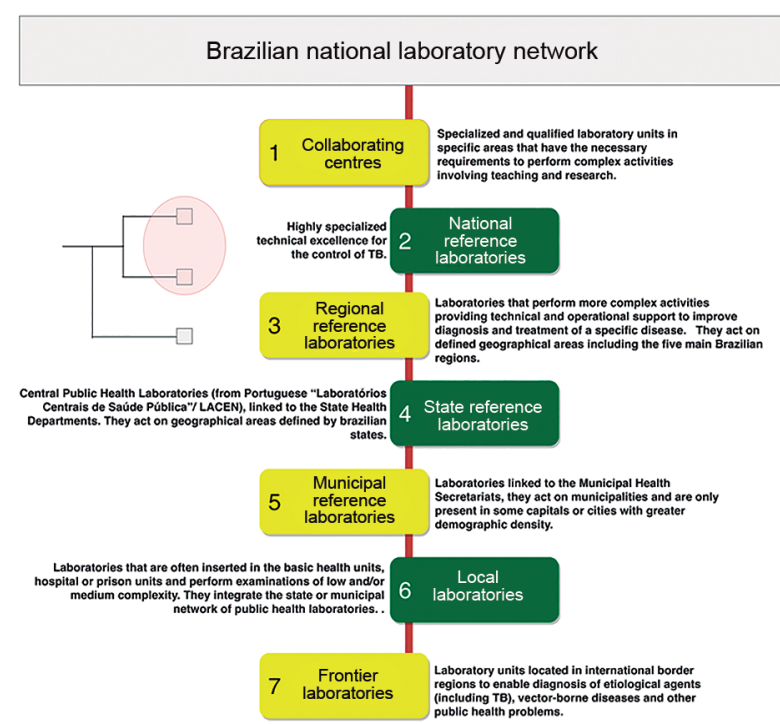

Fig. 1: the Brazilian National System of Public Health Laboratories network classified by degree of complexity highlighting the two levels capable to elaborate a national genetic database for tuberculosis (TB) surveillance.
960) are performed. However, between 2014 and 2015, the Brazilian NPTBC implemented the molecular diagnostics technology Xpert ${ }^{\circledR}$ MTB/RIF (rifampicin) in 92 municipalities with high disease burden. ${ }^{(20)}$ More recently, the identification of MTBC isolates by the rapid immunochromatographic test SD-Bioline TB Ag MPT 64 (Standard Diagnostics, Seoul, South Korea) was implement in Brazil.

The phenotypic drug-susceptibility tests (DST) for first line drugs are performed in all State Reference Laboratories named Laboratório Central (LACEN) and are based on the MGIT-960 SIRE kit (MGIT-960; Becton Dickinson Diagnostic Systems, Sparks, MD). At municipality level, the molecular drug-susceptibility test Xpert-Ultra ${ }^{\circledR}$ MTB/RIF (Cepheid, Sunnyvale, EUA) (21) is performed for detection of RIF-R while at the regional reference laboratories, GenoType ${ }^{\circledR}$ MTBDRplus and GenoType ${ }^{\circledR}$ MTBDRsl (Hain Lifescience $\mathrm{GmbH}$, Nehren, Germany) are used, detecting respectively mutations associated with rifampicin and isoniazid resistance, and mutations associated with fluoroquinolones and second-line injectable drugs.

Currently, the DST for second-line drugs is carried out only in three laboratories in Brazil: at the National Reference Centre (Centro de Referência Professor Hélio Fraga - CRPHF) and at the Laboratório de Bacteriologia e Bioensaios both belonging to the Oswaldo Cruz Foundation (Fundação Oswaldo Cruz - Fiocruz) in Rio de Janeiro, and at the LACEN in São Paulo.

Focusing more on epidemiological surveillance, the Notifiable Diseases Information System for Tuberculosis (SINAN-TB) is the main source for professionals of health surveillance services for data analysis and for planning and monitoring actions towards TB control at the three government levels: federal, state and municipality. A recent study demonstrated the current algorithm used by SINAN-TB, which has a unique identifier per person, integrated with other information systems and built on new technologies, so that TB data transfer and analysis is more streamlined in Brazil. Interestingly, the only results from a molecular diagnostic test that are included in the SINAN-TB are those of the Xpert MTB/RIF assay. ${ }^{(22)}$

Data analysed - Among a total of 240 manuscripts published between 1996 and 2019, 169 on RFLP-IS6110 and 71 on MIRU-VNTR, we considered 56 eligible for our study. The BVS database constitutes mostly of PubMed publications along with some duplicated articles within the rest of its own databases. Fig. 2 demonstrates details about the screening process and finally: 17 manuscripts on MIRU-VNTR $17^{(23-39)}$ and 42 on RFLP-IS6110 were considered, ; $^{23,26,31,32,40-75)}$ three manuscripts considered both methodologies.

In the case of MIRU-VNTR data, some articles were excluded because they only contained information on M. tuberculosis var. bovis $(\mathrm{n}=5) ;{ }^{(76,77,78,79,80)}$ no data on genotyping were available $(\mathrm{n}=6) ;(49,66,81,82,83,84)$ incomplete information on genetic diversity $(n=3)$ $(85,86,87)$ or genotyping data is mixed with samples from other countries $(\mathrm{n}=3){ }^{(84,88,89)}$

Regarding manuscripts on RFLP-IS6110, we excluded those with data on $M$. bovis only $(\mathrm{n}=4) \cdot{ }^{(90,91,92,93)}$ without visible on genotyping $(\mathrm{n}=8)^{(33,94,95,96)}$ did not present data 
regarding genetic diversity $(\mathrm{n}=9) ;(24,97,98,99,100,101,102,103)$ were related to nontuberculous mycobacteria (NTM) $(\mathrm{n}=4) ;{ }^{(104,105,106,107)}$ were performed in other countries $(\mathrm{n}=5) ;(88,108,109,110,111)$ did not target IS6110 for RFLP $(\mathrm{n}=7)^{(112-118)}$ or were data presented as part of a thesis manuscript and had not been peer reviewed $(n=4)$.

We observed that RFLP-IS6110 analysis was the first technique to evaluate genetic diversity of $M$. tuberculosis in Brazil over two decades ago, and data using this technique are still being published. This technique has nowadays been substituted almost completely by MIRUVNTR typing (Supplementary data I).

The geographical map of Brazil with TB incidence, study distribution based on sampling and manuscript authorship is presented by Fig. 3. Fig. 3A demonstrates the spatial location of the country divided in five regions and 27 states demonstrating a considerable difference of incidence per state, with the states of Amazonas (AM North) and Rio de Janeiro (RJ - Southeast) presenting the highest values (72.9 and 66.3 per 100.000 inhabitants).

Studies using MIRU-VNTR or RFLP-IS6110 were performed in all regions of Brazil and in $16(59 \%)$ of the states (including the Federal District) but most $(n=40 / 56)$ were performed in the Southeast region, including 17 in Rio de Janeiro and 15 in São Paulo states; and in the South, represented by 12 studies from Rio Grande do Sul and three from Paraná states. In the North, three studies were represented from Pará State while the Central West region harbored five studies, all from Goiás State (Fig. 3).

RLFP data-analysis - Among the Brazilian regions, the largest number of studies, using RFLP-IS6110, was observed in the Southeast region, with more than $70 \%$ of all publications, followed by the South and Central West regions that, together, do not reach $25 \%$. The description of clustering rate and number of IS6110 copies can be found in Table I, and the Southeast region includes studies comprising all the constituent states with a clustering in the general population ranging from 6 to $56.2 \%$. Among the vulnerable populations studied, transmission rate was observed of 53\% among HIV patients (71) and $84 \%$ among prisoners. ${ }^{(52)}$

For São Paulo, the state with the biggest population and economic growth, some specific populations showed high clustering rate, such as patients with resistant TB $(52.3 \%){ }^{(46)}$ extensively resistant $(52.8 \%)^{(54)}$ and prisoners $(55.9 \%){ }^{(60)}$ Rio de Janeiro and São Paulo were the municipalities with the highest number of publications using RFLP-IS6110 (11 each) and demonstrated an increase in the rate of grouping/transmission over time. Among the studies analysed, one study conducted in the central region of São Paulo reported the highest clustering rate $(56.2 \%)$ and in this study, they sought to verify the impact of migration on the recent transmission of

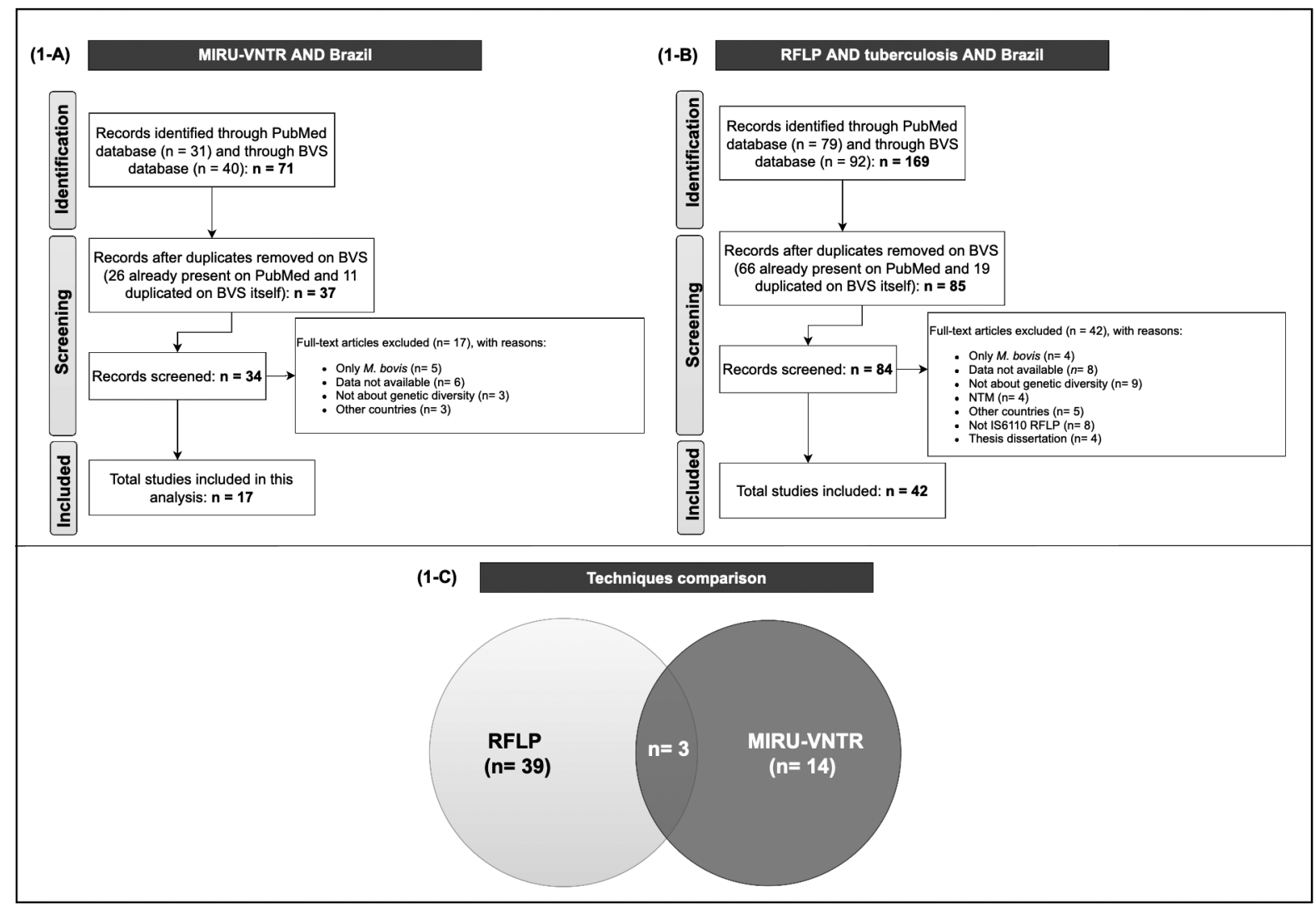

Fig. 2: the PRISMA flow diagram for each genotyping technique demonstrating the total of studies selected for this literature review: 1-A) mycobacterial interspersed repetitive unit-variable variable number tandem repeat (MIRU-VNTR) and 1-B) restriction fragment length polymorphism (RFLP-IS6110). 1-C) The 57 studies of Mycobacterium tuberculosis genotyping in Brazil and their distribution according to each method. 
A

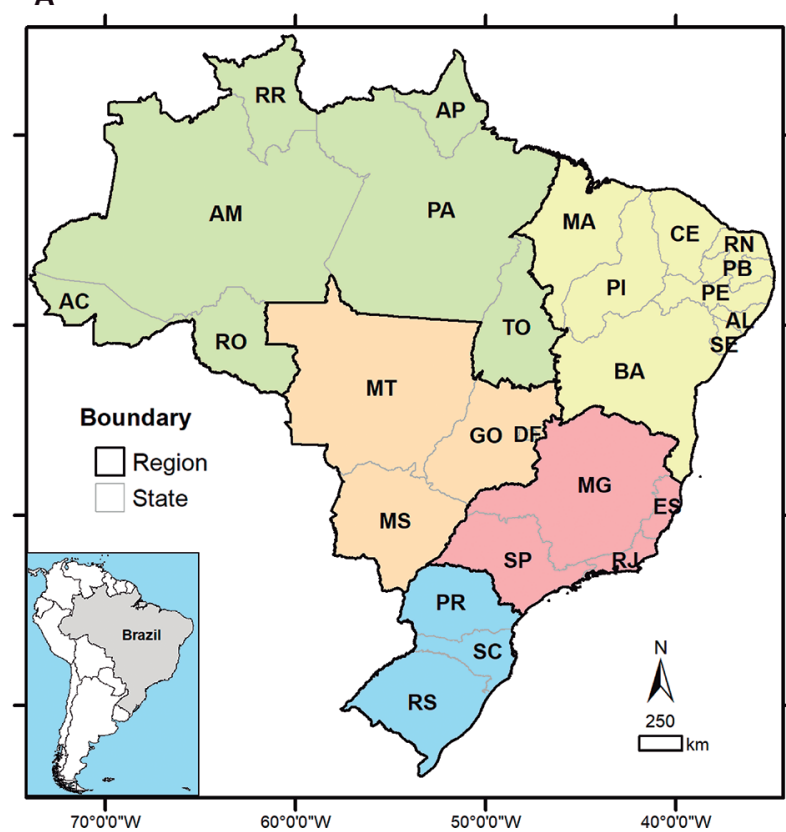

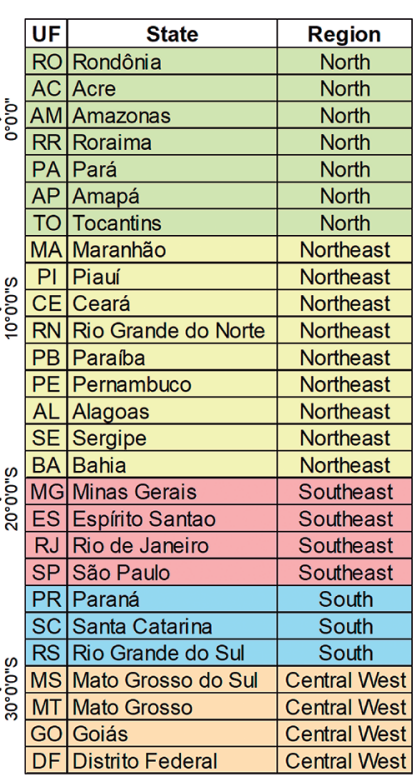

B

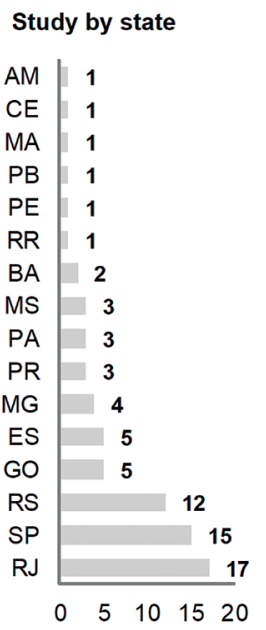

Geographic Projection Datum: SIRGAS2000

Source: IBGE (2018)

Fig. 3: studies distribution based on genotyping by restriction fragment length polymorphism (RFLP-IS6110) and mycobacterial interspersed repetitive unit-variable variable number tandem repeat (MIRU-VNTR) in Brazil. (A) Spatial localisation; (B) number of studies by states.

TB. Despite the high percentage found in that study, there seems to be limited contribution of migration in the transmission of TB to Brazilians and vice versa. ${ }^{(50)}$

For Espírito Santo State, the clustering rate ranged from 40 to $48 \%$; however, as most studies comprised periods of time and/or were overlapping, it was not possible to infer a tendency for increase or decrease in this particular state. However, the incidence of TB in Espirito Santo state seems to be highly influenced by a small set of strains that circulate actively. ${ }^{(53,69)}$

Data from Minas Gerais State shows that its rate of clustering was the lowest in the Southeast region, ranging between $6.4 \%$ and $25.4 \%$, suggesting a low recent rate of TB transmission in this state, including patients with MDR-TB; this might have been influenced however by the low sampling.(26)

Five publications were from the South region, all from the state of Rio Grande do Sul; strains with one to 18 copies of IS6110 have been reported and the percentage of grouping ranged from 36 to $42.9 \%$ for the general population and from $38 \%$ to $68.6 \%$ for the population with MDR-TB. Despite the small number of publications, studies with MDR-TB patients suggesting an increase of MDR-TB transmission during the studied period, a particular problem of this Southern state and probably associated with HIV infection.

In Mid-West Brazil, more specifically in the Goiás State, polymorphism is observed in TB resistant and TB-MDR strains, suggesting a high rate of primary resistance. Two studies in Mato Grosso State, carried out exclusively upon the indigenous population, demonstrated a high clustering rate of $63.5 \% \%^{(64)}$ and $69 \%{ }^{(51)}$ typical for high transmission rates among such populations.
In the Northeast region of the country, the only study we found was that of Silva et al. ${ }^{(119)}$ (evaluating isolates from Bahia State that had been collected between March and June 2008, reporting M. tuberculosis with a number of IS6110 copies ranging between 2 and 16 , with a cluster rate of $26.7 \%$.

Similarly, the North region was also represented by a single study conducted in the State of Roraima which borders with Venezuela and Guyana and has an important portion of their TB cases associated with indigenous population, constituting 70\% of TB cases (2015-2016) and presenting a clustering rate of $30 \% \cdot{ }^{(31)}$ This clustering rate is low when compared to other regions of the country what might be related to a large flow of people, being a border region.

MIRU-VNTR data-analysis - We obtained MIRUVNTR genotypes from 1,613 MTBC isolates and conducted the analysis using 12,15 or 24 MIRU-VNTR alleles for constructing genetic patterns. Patterns of 24-MIRU-VNTR were available for 1,041 (64.5\%) isolates from all states except from Goiás and Paraná. The data demonstrated that genotypes are not exclusively of a specific state (Fig. 4). Because 24-MIRU-VNTR typing is also considered adequate for phylogenetic analysis, we are puzzled by the bimodal and mostly regionindependent grouping within the MST tree with strains from Rio de Janeiro State at the central node (Fig. 4C).

Upon analysis of the number of studies on MIRU-VNTR typing in the country, we observed that the Southeast and South regions present the highest number $(82.4 \%$; 14/17) and in general, these studies demonstrated that the MIRU-VNTR present a high discriminatory power. Two of these with the largest sampling ${ }^{(28,29,30)}$ showed a 
low rate of clustering in the $M$. tuberculosis population ( 0.13 and 0.28 , respectively). Additionally, two studies $^{(32,33)}$ investigated isolates from the same patient with up to three different loci and upon further characterisation, such closely related MIRU-VNTR types, demonstrated to belong to the same strain.

The clustering rate according to each MIRU-VNTR set of 12,15 and 24 loci was $73 \%, 33 \%$ and $28 \%$, respectively (Table II). Among the 24 and 15 loci evaluated, 4052_QUB26, 2163b_QUB11b, 424_Mtub04, 802_MIRU40, 1955_Mtub21, 2696_MIRU26, were considered highly discriminant. Regarding the 24 and 15 loci evaluated, 802_MIRU40, 2696_MIRU26, 2531 MIRU23, were considered highly discriminant and present in 12 and 24 loci analysis, while 802_MIRU40, 2696_MIRU26 and 960_MIRU10 were highly discriminant and commonly present in 12 and 15 loci analysis.

The 802 MIRU40 and 2696 MIRU26 were the highly discriminant among the three dataset and 960 MIRU10 were highly discriminant in 12 and 15 loci and moderately discriminant in 24 loci analysis (Supplementary data II).

The assignation (lineage and/or sublineage) of the strains using TBminer is presented in Supplementary data III. All assignations in green are reliable (at least 2 classifications providing the same result). Lineage 4 , mainly Latin-American Mediterranean (LAM) is predominant in all states, but Lineage 1 is mainly isolating from patients in the Pará State, and Lineage 3 is predominantly from Rio Grande do Sul State. Although the observation of the potential concentration $M$. bovis in Goiás, and Lineage 5 (M. africanum) in Rio de Janeiro states, there is not a consensus between the two classifications available.

\section{DISCUSSION}

This study presents the data on the genetic diversity of M. tuberculosis and TB transmission within the new era of global TB monitoring, discussing aspects of TB molecular epidemiology in Brazil previously pointed out in a translational research perspective - "from bench to bedside"."120)

In the light of the Genomic Era, a recent study conducted in England described benefits of TB molecular strain-based cluster investigations (CIs) into a translational approach by identifying new epidemiological links between cases and taking public health action, as well as refuting transmission and saving resources. (121) According to these results, molecular typing is efficient for decreasing transmission and adds value for improving public health in low disease prevalence and high resource setting.

Even though $\mathrm{Xpert}^{\mathbb{R}}$ MTB/RIF has been implemented in Brazil since 2014, this test does not provide information about MTBC lineages or transmission that could be useful for epidemiological studies and clinical decision-making. Current trends in this direction, point to the use of a new technologies that are able to provide both molecular DST and epidemiological information based on next generation sequencing (NGS) using whole-genome sequencing (WGS). ${ }^{(122)}$
A recent review ${ }^{(6)}$ showed that between 2009 and 2016 , a total of $\$ 4.6$ billion was invested into TB research, mostly for the development of new diagnostics tools, drugs, and vaccines (61\%). Studies on genetic variability are welcome but should go a step further towards translational sciences. Therefore, genotyping tools are important not only to achieve a faster diagnostic and

TABLE I

Summary of restriction fragment length polymorphism-IS6110 (RFLP-IS6110) genotyping publications

\begin{tabular}{|c|c|c|c|c|c|c|}
\hline & 莺 & 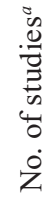 & $\%$ & 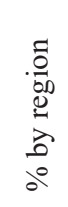 & 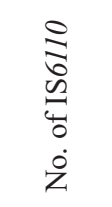 & $\begin{array}{l}\dot{0} \\
\tilde{0} \\
\Xi \\
0 \\
. \Xi \\
0\end{array}$ \\
\hline \multirow{4}{*}{ Southeast } & SP & 11 & 28.2 & \multirow{4}{*}{74.4} & 2 to 21 & 22 to 56 \\
\hline & ES & 5 & 12.5 & & NR & 40 to 48 \\
\hline & $\mathrm{RJ}$ & 11 & 28.2 & & 2 to 22 & 19 to $84^{b}$ \\
\hline & MG & 2 & 5.1 & & 1 to 18 & 6 to 25 \\
\hline \multirow{3}{*}{ South } & PR & 0 & 0 & \multirow{3}{*}{10.3} & - & - \\
\hline & $\mathrm{SC}$ & 0 & 0 & & - & - \\
\hline & $\mathrm{RS}$ & 4 & 10.3 & & 1 to 18 & 36 to $69^{c}$ \\
\hline \multirow{4}{*}{ Central West } & $\mathrm{GO}$ & 2 & 5.1 & \multirow{4}{*}{10.3} & 1 to 14 & 0 \\
\hline & MT & 0 & 0 & & - & - \\
\hline & MS & 2 & 5.1 & & 4 to 17 & 64 to $69^{d}$ \\
\hline & DF & 0 & 0 & & - & - \\
\hline \multirow{7}{*}{ North } & TO & 0 & 0 & \multirow{7}{*}{2.6} & - & - \\
\hline & PA & 0 & 0 & & - & - \\
\hline & AP & 0 & 0 & & - & - \\
\hline & RR & 1 & 2.6 & & NR & 30 \\
\hline & $\mathrm{AM}$ & 0 & 0 & & - & - \\
\hline & $\mathrm{RO}$ & 0 & 0 & & - & - \\
\hline & $\mathrm{AC}$ & 0 & 0 & & - & - \\
\hline \multirow{9}{*}{ Northeast } & MA & 0 & 0 & \multirow{9}{*}{2.6} & - & - \\
\hline & PI & 0 & 0 & & - & - \\
\hline & $\mathrm{CE}$ & 0 & 0 & & - & - \\
\hline & RN & 0 & 0 & & - & - \\
\hline & PB & 0 & 0 & & - & - \\
\hline & $\mathrm{PE}$ & 0 & 0 & & - & - \\
\hline & $\mathrm{AL}$ & 0 & 0 & & - & - \\
\hline & SE & 0 & 0 & & - & - \\
\hline & BA & 1 & 2.6 & & 2 to 16 & 27 \\
\hline \multicolumn{2}{|l|}{ TOTAL } & 39 & 100 & 100 & 1 to 22 & 0 to 84 \\
\hline
\end{tabular}

$a$ : for these calculations, articles that analysed samples from more than one state in the same study were disregarded; $b$ : study with inmate population; $c$ : tuberculosis multidrug resistant (TB-MDR) population study; $d$ : study with indigenous population; NR: not reported. 

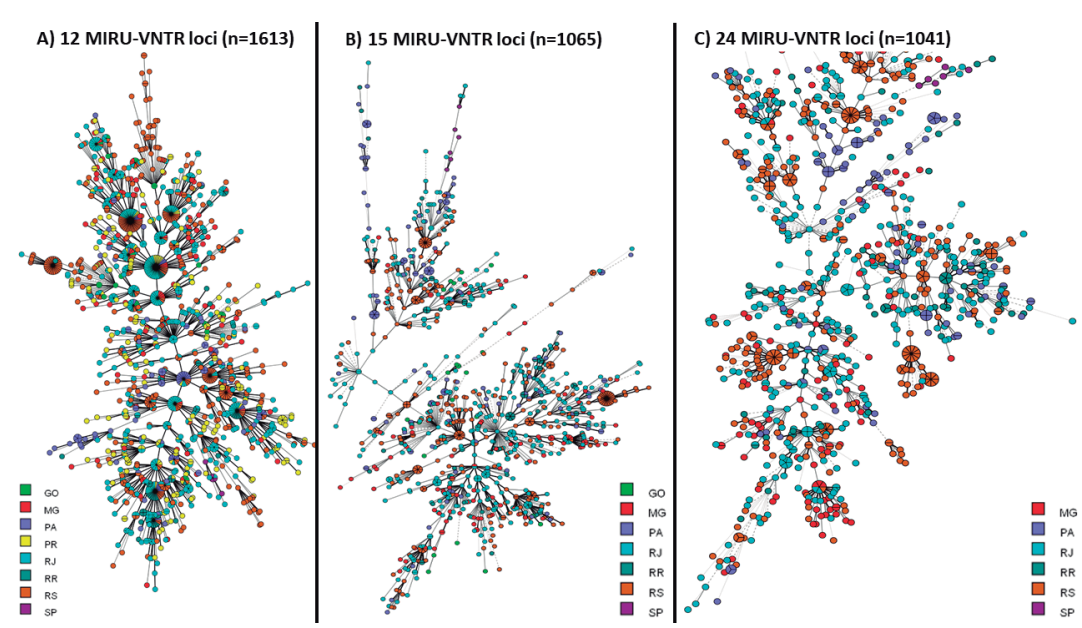

Fig. 4: minimum spanning trees (MST) demonstrating the genetic diversity of Mycobacterium tuberculosis in Brazil based on consideration of 12,15 or 24 mycobacterial interspersed repetitive unit-variable variable number tandem repeat (MIRU-VNTR) alleles and considering a different dataset according to the method's sampling. Samples are coloured according to state origin: Goiás (GO), Minas Gerais (MG), Rio de Janeiro (RJ), Rio Grande do Sul (RS), São Paulo (SP), and Pará (PA).

treatment scheme, but also to be implemented at least at the level of regional reference laboratories as a measure of monitoring and controlling TB.

The Brazilian TB surveillance actions include home visit for new case and summoning of possible cases of TB infection in hospitals and other institutions, as well as follow-up and closure of cases. ${ }^{(13,22)}$ Currently, strain typing (that would be preferably by 24 -loci MIRU-VNTR typing) is not part of routine surveillance in any institution in Brazil, only for basic research.

The present study demonstrates that over the last two decades, MIRU-VNTR has been used less for genotyping than the previous gold standard technique (RFLPIS6110), not only because of earlier implementation of the latter (1993 versus 2008), but also due to its higher cost. This is of particular importance for a country with a considerable TB incidence such as Brazil (rate of 33.5 per 100,000 inhabitants). However, implementation of such technology to screen only MDR-TB cases would be already a great step ahead.

The use of international databases not only allows local or national genotyping studies, but evaluation of genetic composition of M. tuberculosis strains on a larger and even on a global level. In particular for MIRUVNTR, besides SITIVIT2, there is another international database that allows comparison and classification to the lineage level of local genotypes (MIRU-VNTRplus - http://www.miru-vntrplus.org), which has a collection of 186 strains representing the major MTBC lineages. For each strain species, lineage and epidemiologic information is stored together with information regarding the copy numbers of 24 MIRU loci, spoligotyping patterns, regions of difference (RD) profiles, single nucleotide polymorphisms (SNPs), susceptibility data and RFLP-IS6110 fingerprint images for all isolates. ${ }^{(123,124)}$ However, because this database is limited to the input of genotypes from 500 isolates per analysis and our sampling was composed of 1,613 entries for MIRU-VNTR, we used the Bionumerics v.7.6 software (Applied Maths, Sint-Martens-Latem, Belgium) for analysis.
The limitations of RFLP-IS6110 are due to the requirement of large amounts of purified DNA in a more complicated methodology with extensive and laborious steps during data analysis for comparison of data generated in different laboratories by considering internal and external molecular weight markers. Comparison of such data requires the use of specialised programs such as Bionumerics and considerable experience on part of the user, for pattern analysis.

Although a considerable number of studies in Brazil performed genotyping by RFLP-IS6110 have been published, they mostly report on regional patients where a single laboratory analysed the samples without inter-laboratory comparison because of the afore mentioned characteristics of the technique. In addition, no robust international database of RFLP-IS6110 profiles is accessible. There is one centralised database at the National Institute for Public Health and the Environment (RIVM, Bilthoven, the Netherlands) but only accessible for collaborators. ${ }^{(73,94)}$

Although this technique has been used to date, MIRU-VNTR analysis has already proved its robustness and equivalence to the results obtained by RFLP- IS6110. ${ }^{(125)}$ Moreover, it still has the advantage of allowing the analysis of isolates with fewer copies of IS6110 which is not considered a good RFLP-IS6110 method for these cases.

The higher discriminatory power of MIRU-VNTR compared to other genotyping techniques is already widely known, ${ }^{(126)}$ also showing a range of polymorphism, such that loci 10,23, 26, 31 and 40 have greater discriminatory power than the others. Additionally, its value has been demonstrated for detecting relapse cases, reinfection, and mixed infections. ${ }^{(127)}$

Comparing the MIRU-VNTR discriminatory power, this study corroborates a recent review evaluating 56 studies (39 from Asia, seven from America, six from Africa, three from Europe and one from a different country), ${ }^{(128)}$ demonstrated that MIRU10, MIRU26, QUB26, MIRU40, QUB11b and Mtub21 was reported to be the loci with the highest discriminatory powers $(h>0.6)$, 
TABLE II

Clustering analysis of mycobacterial interspersed repetitive units - variable number tandem repeat (MIRU-VNTR)

\begin{tabular}{|c|c|c|c|c|c|c|c|}
\hline Typing methods & $\mathrm{n}$ & $\begin{array}{c}\text { No. of different } \\
\text { patterns }\end{array}$ & $\begin{array}{l}\text { No. of } \\
\text { clusters }\end{array}$ & $\begin{array}{l}\text { No. of clusters } \\
\text { isolates }\end{array}$ & $\begin{array}{l}\text { No. of unique } \\
\text { isolates }\end{array}$ & $\%$ in cluster & $\begin{array}{l}\text { Size of } \\
\text { clusters }\end{array}$ \\
\hline MIRU-VNTR 12 loci & 1,613 & 26 & 11 & 40 & 15 & $73 \%$ & $2-7$ \\
\hline MIRU-VNTR 15 loci & 1,065 & 821 & 106 & 350 & 715 & $33 \%$ & $2-23$ \\
\hline MIRU-VNTR 24 loci & 1,041 & 845 & 91 & 287 & 754 & $28 \%$ & $2-11$ \\
\hline
\end{tabular}

in Brazilian population, we also present MIRU 23 and Mtub04 with high discriminatory power. These eight loci can be considered in studies that need to be faster and less costly. Studies supported by the Brazilian government exploring and describing the MTBC genetic diversity into the five main regions have correlated the emergence of drug resistant-TB to RD ${ }^{\text {rio }}$ (LAM sublineage) strains in South and Southeast regions ${ }^{(23,129)}$ and to the T lineage in the North. ${ }^{(130)}$

Concerning the phylogenetic network, the central position is not meaningful in the context of many diverse isolates. The ancestor that gave rise to all these strains has no good representative today, in this way the centre is highly dependent on the frequency of the samples, and the strains that have by chance quite average values for the genotyped loci. There is little spatial structure in Brazil. This can also be seen in the assignation to lineages as described above. Regarding the lineages, the Brazilian profile observed in this demonstrate the higher frequency of Lineage 4, mainly LAM genotype and the higher frequency of Lineage 1 in Pará State. ${ }^{(130,131,132,133)}$ The presence of $M$. tuberculosis var. bovis among human strains was not reported so far, and $M$. tuberculosis var. africanum was recently reported as a single isolate from a patient from Pará State. ${ }^{(134)}$

This study has some limitations, and they are mostly related to data correlation since some articles do not show genotype data (the number of each MIRU-VNTR loci, or RFLP-IS6110 profile), so they were excluded from the analysis. Some publications repeat data from previous studies without allowing sample identification, so it was not possible to evaluate the real frequency of genotypes isolates per Brazilian state or region.

On December 23rd of 2019, the Brazilian Secretary of Health Surveillance has published the list of approved National and Regional Reference Laboratories for TB and atypical mycobacteria (NTM), aiming at the establishment of the National Network of Public Health Laboratories for the next 5 years. Institutes on the national level are the National Reference Laboratory Professor Hélio Fraga (CRPHF) of the Fundação Oswaldo Cruz. At the regional level are the Regional Reference Laboratories: The Laboratory of Bacteriology and Bioassays of the National Institute of Infectious Diseases Evandro Chagas (INI, FIOCRUZ), the Central Public Health Laboratory of Amazonas (LACEN, AM), the Central Laboratory of Public Health of Espírito Santo (LACEN, ES); and the Central Public Health Laboratory of the Federal District (LACEN, DF).
Regarding the advances on technology evolution, studies have demonstrated that WGS has the greater discriminatory power for epidemiological compared to genotyping methods. For example, to track TB transmission, it was already established that, based on WGS data, a genetic distance from zero to five SNPs separating patient isolates, are present in linked cases such as household contacts; a genetic distance from five to 12 SNPs is for related cases and more than 12 SNPs was defined to classify epidemiologically unrelated cases. ${ }^{(135,136)}$ Besides that, compared to the commercial genotyping methods or Sanger sequencing, analysis based on WGS display a greater panel of mutations associated to drug resistance.

Taking out $23 \mathrm{M}$. bovis genomes, there are few studies in Brazil related to WGS applied to M. tuberculosis so far (around 765 genomes): five related to drug resistance characterisation ${ }^{(122,137,138,139,140)}$ and four related to epidemiological approach ${ }^{(29,141,142,143)}$ we did not include them in this current analysis. Such national studies confirm the potential of WGS for molecular epidemiology approach compared to genotyping. In Supplementary data IV there is a list of all published MTBC genomes isolated in Brazil so far, which is the first version of what should become an interactive database of Mycobacterium genomes from patients from Brazil, including MTBC, M. leprae and NTM presently under construction at http://www.ioc.fiocruz.br/gemibra/. Part of these MTBC genomes are also available at a website http:// cplp-tb.ff.ulisboa.pt/, a TB Molecular Epidemiology Database for the Community of Portuguese Speaking Countries (CPLP). ${ }^{(89)}$

Even through the natural progression towards WGS is going on, applying MIRU-VNTR and creating a national genotyping database for TB surveillance is more feasible, at least for a while, than WGS at the regional and national reference laboratories. However, in parallel, we could give rise to an interactive national database for WGS, focusing on the genetic structure of MTBC in Brazil, for research and for TB surveillance.

Thus, a similar long-term analysis performed in this study could address a better understanding of the TB dynamics in all of Brazil and refocus the attention towards the gold standard of surveillance. This is the same direction that Singapore has taken by demonstrating that there is a large and heterogeneous distribution of MTBC strains. A universal MTBC typing program coupled with enhanced contact investigations may be useful in further understanding the transmission dynamics of TB locally. ${ }^{(144)}$ 


\section{In conclusion}

Tracing TB cases and their contacts is of vital importance for the control of TB in high burden countries like Brazil. Research on TB genetic diversity and molecular epidemiology in Brazilian territory was more frequent in South and Southeast and it is imperative to reinforce the need of molecular epidemiology surveillance in the central and northern states. This could be achieved by the intensive training of more laboratory professionals and supply of the materials needed to perform the technique. A high but heterogeneous rate of TB transmission was observed in Brazilian regions. This study highlights the importance of including genotypic analysis by MIRU-VNTR in TB surveillance, at least of drugresistant cases, and of maintaining a hierarchical flow of data between laboratories in the NPCT network. Thus, we propose an implementation of molecular typing techniques for TB transmission detection based initially on MIRU-VNTR towards WGS, as well as the creation of a national database would improve our efforts to decrease the incidence of this challenging disease.

\section{List of abbreviations}

AC: Acre; AFB: Acid-fast bacilli; AL: Alagoas; AM: Amazonas; AP: Amapá; BVS: Biblioteca Virtual em Saúde; BA: Bahia; CE: Ceará; DF: Distrito Federal; DR: direct repeat; ES: Espírito Santo; GIS: geographic information system; GO: Goiás; HBCs: high burden countries; HIV: human immunodeficiency virus; LAM: Latin-American; MA: Maranhão; MDR: multidrug resistant; MG: Minas Gerais; MIRU-VNTRs: mycobacterial interspersed repetitive units-variable tandem repeats of DNA tandem repeats; MS: Mato Grosso do Sul; MT: Mato Grosso; MTBC: Mycobacterium tuberculosis complex; MST: minimum spanning tree; PA: Pará; PB: Paraíba; PE: Pernambuco; PI: Piauí; PR: Paraná; RFLP: restriction fragment length polymorphism; RJ: Rio de Janeiro; RN: Rio Grande do Norte; RO: Rondônia; RR: Roraima; RS: Rio Grande do Sul; SC: Santa Catarina; SE: Sergipe; SDG: sustainable development goals; SISLAB: Sistema Nacional de Laboratórios de Saúde Pública; SP: São Paulo; SUS: Sistema Único de Saúde; TB: Tuberculosis; TO: Tocantins; UHS: unified health system; WHO: World Health Organization; XDR: extensive drug resistant.

\section{ACKNOWLEDGEMENTS}

To all authors who shared their published data in Excel file when they were available only in figures or in text, helping us to speed up the analysis. We are also thankful to Henri Berghs for his great technical assistance with Bionumerics tools; and to Daniel and Edinaldo from DETIN/IOC/FIOCRUZ for technical assistance by hosting the website.

\section{AUTHORS' CONTRIBUTION}

ECC conducted project conception and study designing, literature search, reviewed literature, data collection, data analysis, website conception, and was a major contributor in writing the manuscript; RSS, KMG, AESG, MLC, LMPA have performed the literature review, data-analysis, and manuscript edition; RJPSG performed the spatial analysis; IPF performed the statistical analysis; RBB provided epidemiological information from Brazilian database; AS contributed with literature search, writing the manuscript, and performed
English review; MCS reviewed the manuscript writing and data-analysis; CVN, LF, MCSL and GR has contributed with their experience through manuscript edition and information regarding molecular techniques; VRB contributed writing the manuscript regarding his experience as a physician and the application of genotyping of MTBC; ACB contributed with information about the Brazilian structure of Tuberculosis program; MC developed the website for the whole-genome sequencing database; PNS, HMG, RSD and KVBL were the supervisors. All authors read and approved the final manuscript. The authors declare that they have no competing interests.

\section{REFERENCES}

1. WHO - World Health Organization. Global tuberculosis report 2018. Geneva [Internet]; 2018 (cited 2021 Jan 10). Available from: http:// apps.who.int/iris/bitstream/handle/10665/274453/9789241565646eng.pdf?ua=1.

2. Benavente ED, Coll F, Furnham N, McNerney R, Glynn JR, Campino $\mathrm{S}$, et al. PhyTB: phylogenetic tree visualisation and sample positioning for M. tuberculosis. BMC Bioinformatics. 2015; 16(1): 155.

3. WHO - World Health Organization. The end TB strategy. Geneva [Internet]; 2015 (cited 2021 Jan 10). Available from: http://www. who.int/tb/End_TB_brochure.pdf?ua $=1$.

4. Uplekar M, Weil D, Lonnroth K, Jaramillo E, Lienhardt C, Dias HM, et al. WHO's new end TB strategy. Lancet. 2015; 385(9979): 1799-801.

5. Floyd K, Glaziou P, Houben RMGJ, Sumner T, White RG, Raviglione M. Global tuberculosis targets and milestones set for 2016-2035: definition and rationale. Int J Tuberc Lung Dis. 2018; 22(7): 723-30.

6. Floyd K, Glaziou P, Zumla A, Raviglione M. The global tuberculosis epidemic and progress in care, prevention, and research: an overview in year 3 of the end TB era. Lancet Respir Med. 2018; 6(4): 299-314.

7. Kritski A, Barreira D, Junqueira-Kipnis AP, Moraes MO, Campos MM, Degrave WM, et al. Brazilian response to global end TB strategy: the National Tuberculosis Research Agenda. Rev Soc Bras Med Trop. 2016; 9(1): 135-45.

8. Kritski A, Dalcolmo MP, Mello FCQ, Carvalho ACC, Silva DR, de Oliveira MM, et al. The role of the Brazilian tuberculosis research network in national and international efforts to eliminate tuberculosis. J Bras Pneumol. 2018; 44(2): 77-81.

9. Asgharzadeh M, Rashedi J, Poor BM, kafil HS, Zadeh HM, Ahmadpour E. How molecular epidemiology can affect tuberculosis control in the Middle East countries: a systematic review and metaanalysis. Infect Disord - Drug Targets. 2020; 21: 28-37.

10. Couvin D, Rastogi N. The establishment of databases on circulating genotypes of Mycobacterium tuberculosis complex and web tools for an effective response to better monitor, understand and control the tuberculosis epidemic worldwide. EuroReference - J Ref. 2014; 12: 36-48.

11. Coscolla M. Biological and epidemiological consequences of MTBC diversity. Adv Exp Med Biol. 2017; 1019: 95-116.

12. MS - Ministério da Saúde. NOTA TÉCNICA No. 31/2019-CGDR/. DCCI/SVS/MS. Brasília [Internet]; 2019 (cited 2020 Dec 09). Available from: http://www.saude.pi.gov.br/uploads/warning_document/ file/450/Nota_Técnica_-Regulação.pdf.

13. MS/SVS - Ministério da Saúde/Secretaria de Vigilância em Saúde. Manual de recomendações para o controle da tuberculose no Brasil. 2nd ed. Brasília: Ministério da Saúde/Secretaria de Vigilância em Saúde/Departamento de Vigilância de Doenças Transmissíveis [Internet]; 2011 (cited 2020 Dec 09). 344 p. Available from: https://drive.google.com/file/d/12Sm_BZhR4Cuk5X8YPzgzUXTG38B5_LA7/view. 
14. Liberati A, Altman DG, Tetzlaff J, Mulrow C, Gøtzsche PC, Ioannidis JPA, et al. The PRISMA statement for reporting systematic reviews and meta-analyses of studies that evaluate health care interventions: explanation and elaboration. J Clin Epidemiol. 2009; 6(7): e1000100.

15. Van Embden JDA, Cave MD, Crawford JT, Dale JW, Eisenach KD, Gicquel B, et al. Strain identification of Mycobacterium tuberculosis by DNA fingerprinting: recommendations for a standardized methodology. J Clin Microbiol. 1993; 31(2): 406-9.

16. Glynn JR, Vynnycky E, Fine PEM. Influence of sampling on estimates of clustering and recent transmission of Mycobacterium tuberculosis derived from DNA fingerprinting techniques. Am J Epidemiol. 1999; 149(4): 366-71.

17. Hunter PR, Gaston MA. Numerical index of the discriminatory ability of typing systems: an application of Simpson's index of diversity. J Clin Microbiol. 1988; 26(11): 2465-6.

18. Azé J, Sola C, Zhang J, Lafosse-Marin F, Yasmin M, Siddiqui R, et al. Genomics and machine learning for taxonomy consensus: the Mycobacterium tuberculosis complex paradigm. PLoS One. 2015; 10(7): e0130912.

19. IBGE - Instituto Brasileiro de Geografia e Estatística. Regional divisions of Brazil. The Brazilian Institute of Geography and Statistics [Internet]. 2008 (cited 2021 Jan 06). p. 1. Available from: https:// www.ibge.gov.br/en/geosciences/territorial-organization/regionaldivision/21536-regional-divisions-of-brazil.html? $=\& \mathrm{t}=\mathrm{o}$-que-e.

20. MS - Ministério da Saúde. Rede de teste rápido para tuberculose no Brasil: primeiro ano da implantação [Internet]. Brasília; 2015 (cited 2021 Jan 06). 63 pp. Available from: http://portalarquivos2.saude. gov.br/images/pdf/2016/janeiro/19/rtr-tb-15jan16-isbn-web.pdf.

21. MS - Ministério da Saúde. OFÍCIO CIRCULAR No. 7/2019/ CGDR/.DCCI/SVS/MS - Atualização das recomendações sobre o diagnóstico laboratorial da tuberculose. [Internet]. Brasília; 2019 (cited 2021 Jan 06). Available from: https://central3.to.gov. br/arquivo/472141/.

22. Rocha MS, Bartholomay P, Cavalcante MV, de Medeiros FC, Codenotti SB, Pelissari DM, et al. Sistema de Informação de Agravos de Notificação (Sinan): principais características da notificação e da análise de dados relacionada à tuberculose. Epidemiol Serv Saude [Internet]. 2020 Mar (cited 2020 Dec 11);29(1). Available from: http://www.scielo.br/scielo.php?script=sci_arttext\&pid=S2237$96222020000101201 \& \operatorname{lng}=$ pt\&nrm=iso\&tlng $=$ pt.

23. Lazzarini LCO, Huard RC, Boechat NL, Gomes HM, Oelemann MC, Kurepina N, et al. Discovery of a novel Mycobacterium tuberculosis lineage that is a major cause of tuberculosis in Rio de Janeiro, Brazil. J Clin Microbiol. 2007; 45(12): 3891-902.

24. Noguti EN, Leite CQF, Malaspina AC, Santos ACB, Hirata RDC, Hirata $\mathrm{MH}$, et al. Genotyping of Mycobacterium tuberculosis isolates from alow-endemic setting in northwestern state of Paraná in Southern Brazil. Mem Inst Oswaldo Cruz. 2010; 105(6): 779-85.

25. Dalla Costa ER, Vasconcelos SEG, Esteves LS, Gomes HM, Gomes LL, Da Silva PA, et al. Multidrug-resistant Mycobacterium tuberculosis of the Latin American mediterranean lineage, wrongly identified as mycobacterium pinnipedii (Spoligotype International Type 863 [SIT863]), causing active tuberculosis in South Brazil. J Clin Microbiol. 2015; 53(12): 3805-11.

26. Dantas NGT, Suffys PN, Carvalho WS, Gomes HM, de Almeida IN, de Assis LJ, et al. Genetic diversity and molecular epidemiology of multidrug-resistant Mycobacterium tuberculosis in Minas Gerais State, Brazil. BMC Infect Dis. 2015; 15(1): 1-11.

27. Gomes LL, Vasconcellos SEG, Gomes HM, Elias AR, Rocha AS, Ribeiro SCM, et al. Genetic diversity of the Mycobacterium tuberculosis Beijing family in Brazil and Mozambique and relation with infectivity and induction of necrosis in THP-1 cells. Tuberculosis (Edinb). 2015; 95(Suppl. 1): S190-6.
28. Esteves LS, Dalla Costa ER, Vasconcellos SEG, Vargas A, Ferreira Jr SLM, Halon ML, et al. Genetic diversity of Mycobacterium tuberculosis isoniazid monoresistant and multidrug-resistant in Rio Grande do Sul, a tuberculosis high-burden state in Brazil. Tuberculosis. 2018; 110: 36-43.

29. Conceição EC, Guimarães AES, Lopes ML, Furlaneto IP, Rodrigues YC, da Conceição ML, et al. Analysis of potential household transmission events of tuberculosis in the city of Belém, Brazil. Tuberculosis. 2018; 113: 125-9.

30. Salvato RS, Schiefelbein S, Barcellos RB, Praetzel BM, Anusca IS, Esteves LS, et al. Molecular characterisation of multidrug-resistant Mycobacterium tuberculosis isolates from a high-burden tuberculosis state in Brazil. Epidemiol Infect. 2019; 147: 1-6.

31. Tatara MB, Perdigão J, Viveiros M, Kritski A, da Silva KE, Sacchi FPC, et al. Genetic diversity and molecular epidemiology of Mycobacterium tuberculosis in Roraima State, Brazil. Am J Trop Med Hyg. 2019; 101(4): 774-9.

32. Oelemann MC, Gomes HM, Willery E, Possuelo L, Batista Lima KV, Allix-Béguec C, et al. The forest behind the tree: phylogenetic exploration of a dominant Mycobacterium tuberculosis strain lineage from a high tuberculosis burden country. PLoS One. 2011; 6(3): 1-10.

33. Alves SLA, Metzker FS, de Araújo-Filho JA, Junqueira-Kipnis AP, Kipnis A. Clinical data and molecular analysis of Mycobacterium tuberculosis isolates from drug-resistant tuberculosis patients in Goiás, Brazil. Mem Inst Oswaldo Cruz. 2011; 106(6): 655-61.

34. Valenca MS, da Rocha JZ, Ramis IB, Carrion LL, Madruga C, de Macedo MB, et al. Improving tuberculosis control through the partnership between university and the health system. Rev Soc Bras Med Trop. 2012; 45(4):491-5.

35. Soares RO, de Macedo MB, von Groll A, da Silva PEA. Mycobacterium tuberculosis belonging to family LAM and sublineage RDRio: common strains in Southern Brazil for over 10 years. Braz J Microbiol. 2013; 44(4): 1251-5.

36. Pitondo-Silva A, Santos ACB, Jolley KA, Leite CQF, Darini ALC. Comparison of three molecular typing methods to assess genetic diversity for Mycobacterium tuberculosis. J Microbiol Methods. 2013; 93(1): 42-8.

37. Ribeiro SCM, Gomes LL, Amaral EP, Andrade MRM, Almeida FM, Rezende AL, et al. Mycobacterium tuberculosis strains of the modern sublineage of the beijing family are more likely to display increased virulence than strains of the ancient sublineage. J Clin Microbiol. 2014; 52(7): 2615-24.

38. Machado LNC, Marcondes NR, Leite CQF, Santos ACB, Pavan FR, Baldin VP, et al. First baseline of circulating genotypic lineages of Mycobacterium tuberculosis in patients from the brazilian borders with Argentina and Paraguay. PLoS One. 2014; 9(9): 1-9.

39. Vasconcellos SEG, Acosta CC, Gomes LL, Conceição EC, Lima $\mathrm{KV}$, de Araujo MI, et al. Strain classification of Mycobacterium tuberculosis isolates in Brazil based on genotypes obtained by spoligotyping, mycobacterial interspersed repetitive unit typing and the presence of large sequence and single nucleotide polymorphism. PLoS One. 2014; 9(10): 1-14.

40. Filho LA, Kritski AL, Salles CLG, Sardella IG, Silva MG, Fonseca LS, et al. Mycobacterium tuberculosis typing: usefulness of DREPCR to confirm cross-contamination in the mycobacteriology laboratory of a general reference hospital for AIDS. Int J Tuberc Lung Dis. 2002; 6(2): 150-4.

41. Baptista IMFD, Oelemann MC, Opromolla DVA, Suffys PN. Drug resistance and genotypes of strains of Mycobacterium tuberculosis isolated from human immunodeficiency virus-infected and non-infected tuberculosis patients in Bauru, São Paulo, Brazil. Mem Inst Oswaldo Cruz. 2002; 97(8): 1147-52. 
42. Borsuk S, Dellagostin MM, Madeira SG, Lima C, Boffo M, Mattos I, et al. Molecular characterization of Mycobacterium tuberculosis isolates in a region of Brazil with a high incidence of tuberculosis. Microbes Infect. 2005; 7(13): 1338-44.

43. Cafrune PII, Riley LWW, Possuelo LGG, Valim ARMRM, Borges $\mathrm{M}$, Ribeiro MOO, et al. Recent transmission of tuberculosis involving retired patients. J Infect. 2006; 53(6): 370-6.

44. Calusni ALR, Roscani GN, Villares MCB, Soini H, Graviss EA, Ramos MC. IS6110 restriction fragment length polymorphism of Mycobacterium tuberculosis isolated from patients with pulmonary tuberculosis in Campinas, Brazil. Evidence of intercontinental distribution of strains. Mem Inst Oswaldo Cruz. 2003; 98(5): 655-8.

45. Resende MR, Villares MCB, Ramos MC. Transmission of tuberculosis among patients with human immunodeficiency virus at a University Hospital in Brazil. Infect Control Hosp Epidemiol. 2004; 25(12): 1115-7.

46. Telles MAS, Ferrazoli L, Waldman EA, Giampaglia CMS, Martins MC, Ueki SYM, et al. A population-based study of drug resistance and transmission of tuberculosis in an urban community. Int J Tuberc Lung Dis. 2005; 9(9): 970-6.

47. Valim ARDM, Possuelo LG, Cafrune PI, Borges M, Ribeiro MO, Rossetti MLR, et al. Evaluation and genotyping of multidrug-resistant cases of tuberculosis in southern Brazil. Microb Drug Resist. 2006; 12(3): 186-91.

48. Andrade MKN, Machado SMA, Leite ML, Saad MHF. Phenotypic and genotypic variant of MDR-Mycobacterium tuberculosis multiple isolates in the same tuberculosis episode, Rio de Janeiro, Brazil. Braz J Med Biol Res. 2009; 42(5): 433-7.

49. Augusto CJ, Carvalho WS, de Almeida IN, Figueiredo LJA, Dantas NGT, Suffys PN, et al. Comparative study of RFLP-IS6110 and MIRU-VNTR from Mycobacterium tuberculosis isolated in the state of Minas Gerais, Brazil. Braz J Microbiol. 2018; 49(3): 641-6.

50. Pescarini JM, Simonsen V, Ferrazoli L, Rodrigues LC, Oliveira RS, Waldman EA, et al. Migration and tuberculosis transmission in a middle-income country: a cross-sectional study in a central area of São Paulo, Brazil. BMC Med. 2018; 16(1): 1-10.

51. Sacchi FPC, Tatara MB, De Lima CC, Da Silva LF, Cunha EA, Simonsen $\mathrm{V}$, et al. Genetic clustering of tuberculosis in an indigenous community of Brazil. Am J Trop Med Hyg. 2018; 98(2): 372-5.

52. Sánchez A, Huber FD, Massari V, Barreto A, Camacho LAB, Cesconi V, et al. Extensive Mycobacterium tuberculosis circulation in a highly endemic prison and the need for urgent environmental interventions. Epidemiol Infect. 2012; 140(10): 1853-61.

53. Peres RL, Vinhas SA, Ribeiro FKC, Palaci M, do Prado TN, Reis-Santos B, et al. Risk factors associated with cluster size of Mycobacterium tuberculosis (Mtb) of different RFLP lineages in Brazil. BMC Infect Dis. 2018; 18: 1-10.

54. Gallo JF, Pinhata JMW, Simonsen V, Galesi VMN, Ferrazoli L, Oliveira RS. Prevalence, associated factors, outcomes and transmission of extensively drug-resistant tuberculosis among multidrugresistant tuberculosis patients in São Paulo, Brazil: a cross-sectional study. Clin Microbiol Infect . 2018; 24(8): 889-95.

55. da Costa HCG, Malaspina AC, de Mello FAF, Leite CQF. Tuberculosis in a psychiatric hospital in the state of Goiás, Brazil. J Bras Pneumol. 2019; 32(6): 566-72.

56. Gibson AL, Huard RC, van Pittius NCG, Lazzarini LCO, Driscoll J, Kurepina N, et al. Application of sensitive and specific molecular methods to uncover global dissemination of the major RDRio Sublineage of the Latin American-Mediterranean Mycobacterium tuberculosis spoligotype family. J Clin Microbiol. 2008; 46(4): 1259-67.
57. Malaspina AC, Cavalcanti HR, Leite CQF, Machado SMA, Viana BHJ, Silva RMG, et al. Usefulness of Mycobacterium tuberculosis molecular typing in a tuberculosis low-endemic agro-industrial setting of Brazil. Jpn J Infect Dis. 2008; 61(3): 231-3.

58. Mendes JM, Machado SMA, Lourenço MC, Ferreira RMC, Fonseca LS, Saad MHF. Molecular diversity of Mycobacterium tuberculosis strains in a slum area of Rio de Janeiro, Brazil. J Bras Pneumol. 2008; 34(12): 1063-8.

59. Inumaru VTG, Nogueira PA, Butuem IV, Riley LW, Ferrazoli L. Reactive nitrogen intermediate susceptibility of Mycobacterium tuberculosis genotypes in an urban setting. Int J Tuberc Lung Dis. 2009; 13(5): 665-8.

60. Moreira-Oliveira MS, Oliveira HB, Pace F, Stehling EG, Rocha MMM, Aily DCG, et al. Molecular genotyping and epidemiology of Mycobacterium tuberculosis isolates obtained from inmates of correctional institutions of Campinas, Southeast Brazil. Braz J Infect Dis. 2008; 12(6): 487-93.

61. Perizzolo PF, Dalla Costa ER, Ribeiro AW, Spies FS, Ribeiro $\mathrm{MO}$, Dias CF, et al. Characteristics of multidrug-resistant $\mathrm{Myco}$ bacterium tuberculosis in southern Brazil. Tuberculosis (Edinb). 2012; 92(1): 56-9.

62. Vinhas SA, Palaci M, Marques HS, Lobo de Aguiar PP, Ribeiro FK, Peres RL, et al. Mycobacterium tuberculosis DNA fingerprint clusters and its relationship with $\mathrm{RD}$ (Rio) genotype in Brazil. Tuberculosis. 2013; 93(2): 207-12.

63. Vinhas SA, Jones-López EC, Rodrigues RR, Gaeddert M, Peres RL, Marques-Rodrigues P, et al. Strains of Mycobacterium tuberculosis transmitting infection in Brazilian households and those associated with community transmission of tuberculosis. Tuberculosis. 2017; 104: 79-86.

64. Cunha EA, Ferrazoli L, Riley LW, Basta PC, Honer MR, Maia R, et al. Incidence and transmission patterns of tuberculosis among indigenous populations in Brazil. Mem Inst Oswaldo Cruz. 2014;109(1): 108-13.

65. Eyer-Silva WA, de Almeida MR, Martins CJ, Basílio-de-Oliveira RP, de Araujo LF, Basílio-de-Oliveira CA, et al. Antiretroviral therapy-induced paradoxical worsening of previously healed Mycobacterium haemophilum cutaneous lesions in advanced HIV infection. 2019; 61: 1-6.

66. Pereira AM, Santos LC, Fernandes HB, Alves SLA, Junqueira-Kipnis AP, Kipnis A. Análise molecular de Mycobacterium tuberculosis isolados de pacientes atendidos em Goiânia, Goiás, por meio do rflp-is6110 e do 15 loci miru-vntr. Rev Patol Trop. 2013; 42(3): 275-88.

67. Santos LC, Bousquet HM, Pereira AM, Junqueira-Kipnis AP, Kipnis A. A high prevalence of resistance in new tuberculosis cases of midwestern Brazil. Infect Genet Evol. 2010; 10(7): 1052-7.

68. Gomes T, Vinhas SA, Reis-Santos B, Palaci M, Peres RL, Aguiar PP, et al. Extrapulmonary tuberculosis: Mycobacterium tuberculosis strains and host risk factors in a large urban setting in Brazil. PLoS One. 2013; 8(10): 1-10.

69. Ribeiro FKC, Pan W, Bertolde A, Vinhas SA, Peres RL, Riley L, et al. Genotypic and spatial analysis of Mycobacterium tuberculosis transmission in a high-incidence urban setting. Clin Infect Dis. 2015; 61(5): 758-66.

70. Fandinho FC, Kritski AL, Hofer C, Júnior Conde H, Ferreira RM, Saad MH, et al. RFLP patterns and risk factors for recent tuberculosis transmission among hospitalized tuberculosis patients in Rio de Janeiro, Brazil. Trans R Soc Trop Med Hyg. 2000; 94(3): 271-5.

71. Ivens-de-Araujo ME, Fandinho FC, Werneck-Barreto AM, Gonçalves-Veloso V, Grinstejn B, Lourenço MK, et al. DNA fingerprinting of Mycobacterium tuberculosis from patients with and without AIDS in Rio de Janeiro. Braz J Med Biol Res. 1998; 31(3): 369-72. 
72. Ferreira MM, Ferrazoli L, Palaci M, Salles PS, Medeiros LA, Novoa $\mathrm{P}$, et al. Tuberculosis and HIV infection among female inmates in São Paulo, Brazil: a prospective cohort study. J Acquir Immune Defic Syndr Hum Retrovirol. 1996; 13(2): 177-83.

73. Suffys PN, de Araujo MEI, Rossetti ML, Zaha A, Barroso EW, Barreto AMW, et al. Usefulness of IS6110-restriction fragment length polymorphism typing of Brazilian strains of Mycobacterium tuberculosis and comparison with an international fingerprint database. Res Microbiol. 2000; 151(5): 343-51.

74. Ferrazoli L, Palaci M, Marques LR, Jamal LF, Afiune JB, Chimara $\mathrm{E}$, et al. Transmission of tuberculosis in an endemic urban setting in Brazil. Int J Tuberc Lung Dis. 2000; 4(1): 18-25.

75. Lourenço MCS, Grinsztejn B, Fandinho-Montes FCO, Silva MG, Saad MHF, Fonseca LS. Genotypic patterns of multiple isolates of M. tuberculosis from tuberculous HIV patients. Trop Med Int Health. 2000; 5(7): 488-94.

76. Parreiras PM, Andrade GI, do Nascimento TF, Oelemann MC, Gomes HM, de Alencar AP, et al. Spoligotyping and variable number tandem repeat analysis of Mycobacterium bovis isolates from cattle in Brazil. Mem Inst Oswaldo Cruz. 2012; 107(1): 64-73.

77. Ramos DF, Tavares L, da Silva PEA, Dellagostin OA. Molecular typing of Mycobacterium bovis isolates: a review. Braz J Microbiol. 2014; 372(2): 365-72.

78. Carvalho RCT, Vasconcellos SEG, Issa MA, Soares Filho PM, Mota PMPC, de Araújo FR, et al. Molecular typing of Mycobacterium bovis from cattle reared in Midwest Brazil. PLoS One. 2016; 11(9): e 0162459.

79. de Souza-Filho AF, Osório ALAR, Jorge KSG, Araújo FR, Vidal CES, Araújo CP, et al. Genetic profiles of Mycobacterium bovis from a cattle herd in southernmost Brazil. Semin Agrar. 2016; 37(5): 3719-26.

80. Furlaneto IP, da Conceição ML, Conceição EC, Lopes ML, Rodrigues YC, Macelino BR, et al. Molecular epidemiology of mycobacteria among herds in Marajó Island, Brazil, reveals strains genetically related and potential zoonotic risk of clinical relevance. Infect Genet Evol. 2020; 1(77): 1-7.

81. Lopes JS, Marques I, Soares P, Nebenzahl-Guimaraes H, Costa J, Miranda A, et al. SNP typing reveals similarity in Mycobacterium tuberculosis genetic diversity between Portugal and Northeast Brazil. Infect Genet Evol. 2013; 18: 238-46.

82. Reynaud Y, Millet J, Rastogi N, Van Embden J, Cave M, Crawford $\mathrm{J}$, et al. Genetic structuration, demography and evolutionary history of Mycobacterium tuberculosis LAM9 sublineage in the Americas as two distinct subpopulations revealed by Bayesian analyses. PLoS One. 2015; 10(10): 1-15.

83. Pontual Y, Pacheco VSS, Monteiro SP, Quintana MSB, Costa MJM, Rolla VC, et al. $A B C B 1$ gene polymorphism associated with clinical factors can predict drug-resistant tuberculosis. Clin Sci. 2017; 131(15): 1831-40.

84. de Almeida AL, Scodro RBL, de Carvalho HC, Costacurta GF, Baldin VP, Santos NCS, et al. RD Rio Mycobacterium tuberculosis lineage in the Brazil/Paraguay/Argentina triple border. Tuberculosis. 2018; 110: 68-78.

85. Franco MMJ, Ribeiro MG, Pavan FR, Miyata M, Heinemann MB, de Souza Filho AF, et al. Genotyping and rifampicin and isoniazid resistance in Mycobacterium bovis strains isolated from the lymph nodes of slaughtered cattle. Tuberculosis. 2017; 104: 30-7.

86. Reynaud Y, Zheng C, Wu G, Sun Q, Rastogi N. Bayesian population structure analysis reveals presence of phylogeographically specific sublineages within previously illdefined T group of Mycobacterium tuberculosis. PLoS One. 2017; 12(2): 1-131.
87. Ribeiro MG, Lima MCFF, Franco MMJJ, Megid J, Soares LM, Machado LHAA, et al. Pre-multidrug-resistant Mycobacterium tuberculosis infection causing fatal enteric disease in a dog from a family with history of human tuberculosis. Trans Emerg Dis. 2017; 64(5): 1-7.

88. Acosta CCD, Russomando G, Candia N, Ritacco V, Vasconcellos SEG, Moreira MBP, et al. Exploring the "Latin American Mediterranean" family and the RDRio lineage in Mycobacterium tuberculosis isolates from Paraguay, Argentina and Venezuela. BMC Microbiol. 2019; 19(1): 131-4.

89. Perdigão J, Silva C, Diniz J, Pereira C, Machado D, Ramos J, et al. Clonal expansion across the seas as seen through CPLP-TB database: a joint effort in cataloguing Mycobacterium tuberculosis genetic diversity in Portuguese-speaking countries. Infect Genet Evol. 2018; 72: 44-58.

90. Fisanotti JC, Alito A, Bigi F, Latini O, Roxo E, Cicuta E, et al. Molecular epidemiology of Mycobacterium bovis isolates from South America. Vet Microbiol. 1998; 60(2-4): 251-7.

91. Zanini MS, Moreira EC, Lopes MTP, Oliveira RS, Leão SC, Fioravanti RL, et al. Mycobacterium bovis: polymerase chain reaction identification in bovine lymphonode biopsies and genotyping in isolates from Southeast Brazil by spolygotyping and restriction fragment length polymorphism. Mem Inst Oswaldo Cruz. 2001; 96(6): 809-13.

92. Zanini MS, Moreira EC, Salas CE, Lopes MTP, Barouni AS, Roxo $\mathrm{E}$, et al. Molecular typing of Mycobacterium bovis isolates from south-east Brazil by spoligotyping and RFLP. J Vet Med B Infect Dis Vet Public Health. 2005; 52(3): 129-33.

93. Barouni AS, Augusto C, Queiroz MVNP, Lopes MTP, Zanini MS, Salas CE. BCG lymphadenopathy detected in a BCG-vaccinated infant. Braz J Med Biol Res. 2004; 37(5): 697-700.

94. Suffys PN, Rocha AS, de Oliveira M, Campos CED, Barreto AMW, Portaels F, et al. Rapid identification of Mycobacteria to the species level using INNO-LiPA Mycobacteria, a reverse hybridization assay. J Clin Microbiol. 2001; 39(12): 4477-82.

95. Shaw MA, Atkinson S, Dockrell H, Hussain R, Lins-Lainson Z, Shaw J, et al. An RFLP map for 2q33-q37 from multicase mycobacterial and leishmanial disease families: no evidence for an Lsh/ Ity/Bcg gene homologue influencing susceptibility to leprosy. Ann Hum Genet. 1993; 57(4): 251-71.

96. Clemente WT, Lima SSS, Palaci M, Silva MSN, Rodrigues VFS, Dalla Costa ER, et al. Phenotypic and genotypic characterization of drug-resistant Mycobacterium tuberculosis strains. Diagn Microbiol Infect Dis. 2008; 62(2): 199-204.

97. Aires RS, Matos MAD, Lopes CLR, Teles SA, Kozlowski AG, Silva AMC, et al. Prevalence of hepatitis B virus infection among tuberculosis patients with or without HIV in Goiânia City, Brazil. J Clin Virol. 2012; 54(4): 327-31.

98. Rocha AS, Leite CC, Torres HM, de Miranda AB, Lopes MQP, Degrave WM, et al. Use of PCR-restriction fragment length polymorphism analysis of the hsp65 gene for rapid identification of mycobacteria in Brazil. J Microbiol Methods. 1999; 37(3): 223-9.

99. Zumarraga MJ, Martin C, Samper S, Alito A, Latini O, Bigi F, et al. Usefulness of Spoligotyping in molecular epidemiology of Mycobacterium bovis-related infections in South America. J Clin Microbiol. 1999; 37(2): 296-303.

100. Ribeiro FKC, Lemos EM, Hadad DJ, Leão SC, Viana-Niero C, Dietze R, et al. Evaluation of low-colony-number counts of Mycobacterium tuberculosis on solid media as a microbiological marker of cross-contamination. J Clin Microbiol. 2009; 47(6): 1950-2.

101. Huber FD, Sánchez A, Gomes HM, Vasconcellos S, Massari V, Barreto A, et al. Insights into the population structure of Mycobacterium tuberculosis using spoligotyping and RDRio in a southeastern Brazilian prison unit. Infect Genet Evol. 2014; 26: 194-202. 
102. Prim RI, Schörner MA, Senna SG, Nogueira CL, Figueiredo ACC, de Oliveira JG, et al. Molecular profiling of drug resistant isolates of Mycobacterium tuberculosis in the state of Santa Catarina, southern Brazil. Mem Inst Oswaldo Cruz. 2015; 110(5): 618-23.

103. Santos LC, Kipnis APJ, Kipnis A. Métodos aplicados à epidemiologia molecular do Mycobacterium tuberculosis TT - Methods employed in the molecular epidemiology of Mycobacterium tuberculosis. J Trop Pathol. 2007; 36(1).

104. Oliveira EMD, Morais ZM, Tabata R, Dias RA, de Oliveira RS, Leão SC, et al. Avaliação da virulência em hamsters (Mesocricetus auratus) de estirpes de Mycobacterium avium presentes na população de suínos do Sul do Brasil. Braz J Vet Res Anim Sci. 2002; 39(4): 202-7.

105. Chimara E, Giampaglia CMS, Martins MC, Telles MAS, Ueki SYM, Ferrazoli L. Molecular characterization of Mycobacterium kansasii isolates in the State of São Paulo between 1995-1998. Mem Inst Oswaldo Cruz. 2004; 99(7): 739-43.

106. Telles MAS, Chimara E, Ferrazoli L, Riley LW. Mycobacterium kansasii: antibiotic susceptibility and PCR-restriction analysis of clinical isolates. J Med Microbiol. 2005; 54(10): 975-9.

107. Candido PHC, Nunes LS, Marques EA, Folescu TW, Coelho FS, de Moura VCN, et al. Multidrug-resistant nontuberculous mycobacteria isolated from cystic fibrosis patients. J Clin Microbiol. 2014; 52(8): 2990-7.

108. Shemiakin I, Stepanshina V, Korobova O, Anisimova V, Ivanov I, Lipin M, et al. Genetic typing of Mycobacterium tuberculosis strains by spoligotyping and genome fingerprinting techniques. $\mathrm{Zh}$ Mikrobiol Epidemiol Immunobiol. 2002; 6: 30-5.

109. Vasconcellos SEG, Huard RC, Niemann S, Kremer K, Santos AR, Suffys PN, et al. Distinct genotypic profiles of the two major clades of Mycobacterium africanum. BMC Infect Dis. 2010; 10(1): 1-16.

110. Ritacco V, Iglesias M-J, Ferrazoli L, Monteserin J, Dalla Costa ER, Cebollada A, et al. Conspicuous multidrug-resistant Mycobacterium tuberculosis cluster strains do not trespass country borders in Latin America and Spain. Infect Genet Evol. 2012; 12(4): 711-7.

111. Weisenberg SA, Gibson AL, Huard RC, Kurepina N, Bang H, Lazzarini LCO, et al. Distinct clinical and epidemiological features of tuberculosis in New York City caused by the RD(Rio) Mycobacterium tuberculosis sublineage. Infect Genet Evol. 2012; 12(4): 664-70.

112. Chimara E, Ferrazoli L, Leão SC. Mycobacterium tuberculosis complex differentiation using gyrB-restriction fragment length polymorphism analysis. Mem Inst Oswaldo Cruz. 2004; 99(7): 745-8.

113. Marchi AM, Juttel ID, Kawacubo EM, Dalmarco EM, Blatt SL, Cordova CMM. Evaluation of methods for detection and identification of Mycobacterium species in patients suspected of having pulmonary tuberculosis. Braz J Microbiol. 2008; 39(4): 613-8.

114. Malaghini M, Brockelt SR, Burger M, Kritski A, Thomaz-Soccol V. Molecular characterization of Mycobacterium tuberculosis isolated in the State of Paraná in southern Brazil. Tuberculosis. 2009; 89(1): 101-5.

115. Forestiero FJ, Cecon L, Hirata MH, de Melo FF, Cardoso RF, Cerda A, et al. Relationship of NAT2, CYP2E1 and GSTM1/GSTT1 polymorphisms with mild elevation of liver enzymes in Brazilian individuals under anti-tuberculosis drug therapy. Clin Chim Acta . 2013; 415: 215-9.

116. Riello FN, Brígido RTS, Araújo S, Moreira TA, Goulart LR, Goulart IMB. Diagnosis of mycobacterial infections based on acid-fast bacilli test and bacterial growth time and implications on treatment and disease outcome. BMC Infect Dis. 2016; 16(1): 1-11.

117. Salum KCR, de Castro MCS, Moreira VB, Nani ASF, Kohlrausch FB. Interleukin $1 \alpha$ and $1 \beta$ gene variations are associated with tuberculosis in silica exposed subjects. Am J Ind Med. 2019; 63(1): 74-84.
118. Santos EA, Gonçalves JS, Fleury MK, Kritski AL, Oliveira MM, Velasque LS, et al. Relationship of anti-tuberculosis drug-induced liver injury and genetic polymorphisms in CYP2E1 AND GST. Braz J Infect Dis. 2019; 23(6): 381-7.

119. Silva ACN, Ferrazoli L, Simonsen V, Reis JN, Pereira SM, Carmo TMA, et al. First insights into the genetic diversity of Mycobacterium tuberculosis strains in Salvador, Bahia State, Brazil. Cad Saude Publica. 2011; 27(9): 1859-63.

120. Conceição EC, Lima KVB, Gomes HM, Duarte RS. Molecular epidemiology of tuberculosis in Brazil: a translational research perspective. Rev Panamazonica Saude. 2017; 8(4): 11-3.

121. Hamblion EL, Burkitt A, Lalor MK, Anderson LF, Thomas HL, Abubakar I, et al. Public health outcome of Tuberculosis Cluster Investigations, England 2010-2013. J Infect. 2019; 78(4): 269-74.

122. Feliciano CS, Namburete EI, Plaça JR, Peronni K, Dippenaar A, Warren RM, et al. Accuracy of whole genome sequencing versus phenotypic (MGIT) and commercial molecular tests for detection of drug-resistant Mycobacterium tuberculosis isolated from patients in Brazil and Mozambique. Tuberculosis. 2018; 110: 59-67.

123. Allix-Béguec C, Harmsen D, Weniger T, Supply P, Niemann S. Evaluation and strategy for use of MIRU-VNTRplus, a multifunctional database for online analysis of genotyping data and phylogenetic identification of Mycobacterium tuberculosis complex isolates. J Clin Microbiol. 2008; 46(8): 2692-9.

124. Weniger T, Krawczyk J, Supply P, Niemann S, Harmsen D. MIRU-VNTRplus: a web tool for polyphasic genotyping of $M y-$ cobacterium tuberculosis complex bacteria. Nucleic Acids Res. 2010; 38: 326-31.

125. De Beer JL, Van Ingen J, De Vries G, Erkens C, Sebek M, Mulder A, et al. Comparative study of is6110 restriction fragment length polymorphism and variable-number tandem-repeat typing of $M y$ cobacterium tuberculosis isolates in the netherlands, based on a 5-year nationwide survey. J Clin Microbiol. 2013; 51(4): 1193-8.

126. Sola C, Filliol I, Legrand E, Lesjean S, Locht C, Supply P, et al. Genotyping of the Mycobacterium tuberculosis complex using MIRUs: association with VNTR and spoligotyping for molecular epidemiology and evolutionary genetics. Infect Genet Evol. 2003; 3(2): 125-33.

127. Lymbery AJ, Thompson RCA. The molecular epidemiology of parasite infections: Tools and applications. Mol Biochem Parasitol. 2012; 181(2): 102-16.

128. Ghavidel M, Tadayon K, Mosavari N, Nourian K, Taghanaki HRB, Mohammadi GR, et al. Introducing the best six loci in Mycobacterial Interspersed Repetitive Unit-Variable-Number Tandem Repeat (MIRU-VNTR) typing for Mycobacterium tuberculosis genotyping. Rep Biochem Mol Biol. 2019; 8(3): 335-46.

129. Costa ERD, Lazzarini LCO, Perizzolo PF, Díaz CA, Spies FS, Costa LL, et al. Mycobacterium tuberculosis of the RDRio genotype is the predominant cause of tuberculosis and associated with multidrug resistance in Porto Alegre City, South Brazil. J Clin Microbiol. 2013; 51(4): 1071-7.

130. Conceição ECEC, Rastogi N, Couvin D, Lopes MLML, Furlaneto IPIP, Gomes HMHM, et al. Genetic diversity of Mycobacterium tuberculosis from Pará, Brazil, reveals a higher frequency of ancestral strains than previously reported in South America. Infect Genet Evol. 2017; 56: 62-74.

131. Woodman M, Haeusler IL, Grandjean L. Tuberculosis genetic epidemiology: a latin american perspective. Genes. 2019; 10(1): 1-17.

132. Duarte TA, Nery JS, Boechat N, Pereira SM, Simonsen V, Oliveira $\mathrm{M}$, et al. A systematic review of East African-Indian family of Mycobacterium tuberculosis in Brazil. Braz J Infect Dis. 2017; 21(3): 317-24. 
133. Brynildsrud OB, Pepperell CS, Suffys P, Grandjean L, Monteserin $\mathrm{J}$, Debech N, et al. Global expansion of Mycobacterium tuberculosis lineage 4 shaped by colonial migration and local adaptation. Sci Adv. 2018; 4: 1-12.

134. Rabahi MF, Conceição EC, de Paiva LO, Souto MVML, Sisco MC, de Waard J, et al. Characterization of Mycobacterium tuberculosis var. africanum isolated from a patient with pulmonary tuberculosis in Brazil. Infect Genet Evol. 2020; 85: 104550.

135. Comas I. Genomic epidemiology of tuberculosis. Adv Exp Med Biol. 2017; 1019: 79-93.

136. Merker M, Kohl TA, Niemann S, Supply P. The evolution of strain typing in the Mycobacterium tuberculosis complex. Adv Exp Med Biol. 2017; 1019: 43-78.

137. Salvato RS, Costa ERD, Reis AJ, Schiefelbein SH, Halon ML, Barcellos RB, et al. First insights into circulating XDR and preXDR Mycobacterium tuberculosis in Southern Brazil. Infect Genet Evol. 2020; 78: 1-14.

138. Guimarães AES, Sharma A, Furlaneto IP, Rutaihwa L, Cardoso JF, da Conceição ML, et al. Evaluation of drug susceptibility profile of Mycobacterium tuberculosis Lineage 1 from Brazil based on whole genome sequencing and phenotypic methods. Mem Inst Oswaldo Cruz. 2020; 115: e200520.
139. Feliciano CS, Plaça JR, Peronni K, Silva WA, Bollela VR. Evaluation of resistance acquisition during tuberculosis treatment using whole genome sequencing. Braz J Infect Dis. 2016; 20(3): 290-3.

140. Rossetti ML, Almeida da Silva PE, Salvato RS, Reis AJ, Schiefelbein SH, von Groll A, et al. A highly rifampicin resistant Mycobacterium tuberculosis strain emerging in Southern Brazil. Tuberculosis. 2020; 125: 1-13.

141. Verza M, Scheffer MC, Salvato RS, Schorner MA, Barazzetti FH, Machado HM, et al. Genomic epidemiology of Mycobacterium tuberculosis in Santa Catarina, Southern Brazil. Sci Rep. 2020; 10(1): 1-8.

142. Hadi SA, Kolte IV, Brenner EP, Cunha EAT, Simonsen V, Ferrazoli L, et al. Identification of a predominant genotype of Mycobacterium tuberculosis in Brazilian indigenous population. Sci Rep. 2021; 11: 1-12.

143. Colangeli R, Gupta A, Vinhas SA, Venkata UDC, Kim S, Grady C, et al. Mycobacterium tuberculosis progresses through two phases of latent infection in humans. Nat Commun. 2020; 11: 1-10.

144. Lim LKY, Sng LH, Win W, Chee CBE, Hsu LY, Mak E, et al. Molecular epidemiology of Mycobacterium tuberculosis complex in Singapore, 2006-2012. PLoS One. 2013; 8(12): 1-9. 